\title{
The Possibilities of Using Fruit Waste in Nutrition of Poultry
}

\author{
Ahmet Yusuf Şengüll,a ${ }^{1, a ̈ m e r ~ S ̧ e n g u ̈ l ~}{ }^{2, b, *}$, Aydın Daş̧,c \\ ${ }^{I}$ Department of Animal Science, Faculty of Agriculture, University of Bingöl, 12000 Merkez/Bingöl, Turkey \\ ${ }^{2}$ Department of Animal Science, Faculty of Agriculture, University of Uludağ, 16059 Nilïfer/Bursa, Turkey \\ ${ }^{3}$ Department of Animal Science and Nutrition, Faculty of Veterinary Medicine, Harran University, 63300 Şanluurfa, Turkey
}

"Corresponding author

\begin{tabular}{l|l}
\hline A R T I C L E I N F O & A B S T R A C T \\
\hline Review Article & $\begin{array}{l}\text { Particularly in the fruit juice industry, the remaining peels and pulp parts are not available for } \\
\text { human consumption after the juices are used. It is possible to evaluate these wastes by adding them } \\
\text { to poultry feeds. A number of studies have been conducted by researchers on the nutritional value } \\
\text { of many fruit wastes and on the performance of poultry. Natural antioxidant content has been } \\
\text { reported to have a positive effect on growth, microbial and immunological parameters when high } \\
\text { fruit peels are used as feed additive in poultry feeding. }\end{array}$ \\
$\begin{array}{l}\text { Received : } 10 / 11 / 2018 \\
\text { Accepted : } 28 / 12 / 2018\end{array}$ &
\end{tabular}

Keywords:

Pomegranade peel

Citrus peel

Banana peel

Fruit juice

Poultry feeding

Türk Tarım - Gıda Bilim ve Teknoloji Dergisi 7(5): 724-730, 2019

\section{Meyve Atıklarının Kanatılırın Beslenmesinde Kullanılma İmkânları}

\begin{tabular}{l|l}
\hline M A K A L E B İ L G İ S İ & Ö Z \\
\hline Derleme Makale & $\begin{array}{l}\text { Meyve suyu endüstrisinde kullanılan meyvelerin suyu alındıktan sonra geriye kalan kabuk ve posa } \\
\text { kı́nı insan tüketimine sunulamamaktadır. Söz konusu atıkların kanatlı yemlerine ilave edilerek } \\
\text { değerlendirilmesi mümkün olabilmektedir. Araştırmacılar, birçok meyve atığının besleme } \\
\text { değerleri ve kanatlı hayvanların performansları üzerine etkileri konusunda çalşmalar } \\
\text { yürütmüşlerdir. Doğal antioksidan içeriği yüksek meyve kabuklarının kanatlı hayvanların } \\
\text { beslenmesinde yem katk1 maddesi olarak kullanıldığında, büyüme, mikrobiyal ve immünolojik } \\
\text { parametreler üzerine olumlu etki yaptı̆̆ bildirilmiştir. }\end{array}$ \\
$\begin{array}{l}\text { Geliş } \quad: 10 / 11 / 2018 \\
\text { Kabul }: 28 / 12 / 2018\end{array}$
\end{tabular}

Anahtar Kelimeler:

Nar kabuğu

Narenciye kabuğu

Muz kabuğu

Meyve suyu

Kanatlı hayvanların beslenmesi 


\section{Giriş}

Ülkemizde hızla gelişen kanatlı hayvan yetiştiriciliği yem tüketimini ve yem masraflarını önemli ölçüde arttırmaktadır. Bilindiği gibi, kanatlı sektöründe üretim maliyetinin büyük bir kısmını (yaklaşık \%70'ini) yem masrafı oluşturmaktadır. Bu nedenle, gerek artan yem ihtiyacını karşılamak ve gerekse yem maliyetinin azaltılması amacıyla çeşitli araştırmalar yapılmaktadır. Bu çalışmalarda üzerinde durulan önemli konulardan biri de, alternatif yem kaynaklarının kanatlıların beslenmesinde kullanılma potansiyellerinin araştırılmasıdır. İnsan gıdası olarak tüketilebilen besin maddelerinin hayvan beslemede kullanımı, insanlar ile hayvanlar arasında tüketim rekabeti oluşturduğundan önerilmeyen bir durumdur. İnsanlar tarafından tüketilemeyen birçok besin maddesi hayvanlar için nispeten daha uygun bir besleme potansiyeli taşımakta ve yem kaynağı olarak kullanılabilmektedir.

Özellikle meyve suyu endüstrisinde kullanılan meyvelerin suyu alındıktan sonra geriye kalan posa kısmı insan tüketimine sunulamamaktadır. Söz konusu posaların kanatlı yemlerine uygun bir şekilde ilave edilerek değerlendirilmesi mümkün olabilmektedir. Böylece, hem doğaya bırakılan atıkların azaltılması, hem de ekonomik değeri olmayan atıkların değerlendirilerek yem masraflarının azaltılmasına katkı sağlayacağı düşünülmektedir.

Araştırmacılar tarafindan, birçok meyve atığının besleme değerleri ve kanatlı hayvanların performansları üzerine etkileri konusunda çalışmalar yürütülmüştür. Rizal ve ark. (2010) ve Faiz ve ark. (2017) elma, mango, havuç, narenciye, avakado, kavun ve domates gibi çeşitli meyve atığı karışımlarının broiler piliçlerin rasyonlarına ilave edildiğinde yemden yararlanmayı ve abdominal yağ oranını azalttığını bildirmişlerdir. Doğal antioksidan içeriği yüksek meyve kabuklarının etlik piliçlerin beslenmesinde yem katkı maddesi olarak kullanıldığında, büyüme, mikrobiyal ve immünolojik parametreler üzerine olumlu ekti yaptığı bildirilmiştir (Faiz ve ark., 2017). Besleme çalışmalarında en fazla kullanılan meyve atıklarının kanatlı hayvanların büyüme ve verim performansları üzerine etkileri aşağıda özetlenmiştir.

\section{Muz Kabuğunun Kanatlı Beslenmesinde Kullanımı}

Ülkemizde sevilerek tüketilen bir meyve olan muz, yaş olarak tüketiminin yanında işlenerek de tüketilmektedir. Ülkemizde, 2016 y1lı itibarıyla 62 bin dekarda üretimi yapılan muz bitkisinden 305 bin ton muz meyvesi üretimi gerçekleşmiştir (TÜİK, 2017). Muz meyvesi yaklaşık $1 \mathrm{~g}$ protein, $28 \mathrm{~g}$ karbonhidrat, 2,8 g lif, 0,6 g yağ, $467 \mathrm{mg}$ sodyum, $1 \mathrm{mg}$ potasyum ve 9,2 mg kalsiyum içermekte olup, meyvesinin besin maddesi kompozisyonu muz kabuğunun besin maddesi kompozisyonuna büyük ölçüde benzemektedir (Hernawati ve Aryani, 2007; Someya ve ark., 2002).

Muzun tüketilmesi veya işlenmesi sonucunda elde kalan ve besleme değeri yüksek olan muz kabuklarından ekonomik açıdan istenilen ölçüde istifade edilememektedir. Muz meyvesinin yaklaşık \%18-35'ini kabuk kısmı oluşturmaktadır (Dividich ve ark., 1976; Hang ve ark., 2018). Meyvesi ile karşılaştırıldığında muz kabuğu daha yüksek oranda antioksidan ihtiva etmektedir (Someya ve ark., 2002). Anhwange, (2008) ve Anhwange ve ark., (2009) muz kabuğunun yüksek düzeyde (\%50-59) karbonhidrat, \%0,9 ham protein, $\% 1,7$ ham yağ ve $\% 31,7$ lif içerdiğini bildirmişlerdir. Ayrıca, muz kabuğu çeşitli makro mineraller, tanenler, saponinler gibi çeşitli aktif bileşenler ve A, B, C, E gibi vitaminler de içermektedir (Kanazawa ve Sakakibara, 2000). $100 \mathrm{~g}$ muz kabuğu 7,81 g potasyum, 1,92 g kalsiyum 2,43 g sodyum, 0,061 g demir ve 7,62 g mangan içermektedir (Anhwange, 2008). Yüksek karbonhidrat içeriğinin yanı sıra, içerdiği çeşitli antioksidan ve anti mikrobiyal maddeler ve 40 civarında farklı fenolik bileşen içeren muz kabuğu araştırıcıların dikkatini çekmiş ve kanatlıların beslenmesinde potansiyel karbonhidrat kaynağı olarak kullanılabilirliği araştırılmıştır (Hang ve ark., 2018).

Broiler rasyonlarına 35 gün süreyle $\% 10,20,30$ ve 40 oranlarında kurutulmuş muz kabuğu ilave edilerek yapılan 50 günlük besi çalışmasının sonunda, yemden yararlanma oran1, kandaki kolesterol ve LDL düzeyinde önemli bir değişim gözlenmemiş, HDL ve trigliserit düzeyleri ise önemli düzeyde farklılıklar göstermiştir. Araştırmacılar, muz kabuğunun kanatlı yemlerinin maliyetinin azaltılması amacıyla kullanılabileceğini bildirmişlerdir (Haryanto ve ark., 2016).

Broiler rasyonlarına $\% 5,10$ ve 15 düzeylerinde fermente edilmiş muz kabuğu ve mısır unu karışımı ilave edilerek yapılan çalışmada, canlı ağırlık, yem tüketimi, canlı ağırlı kazancı ve yemden yararlanma oranı bakımından muamele grupları ile kontrol grubu arasında önemli farklılıklar gözlenmemiștir (Anwar ve ark., 2016).

Etlik piliç rasyonlarına \%5, 10 ve 15 oranında fermente edilmiş muz kabuğu ilave edilerek yapılan bir çalışmada, kesim ağırlığı ve karkas ağırlığı bakımından kontrol grubu ile muamele grupları arasında önemli farklılıklar saptanmıştır. Karkas randımanı, Abdominal yağın ağırlıkları ve oranları ise benzer bulunmuştur. Araştırmacı, fermente edilmiş muz kabuğunun \%10 düzeyinde broiler rasyonlarında kullanılabileceğini bildirmiștir (Koni, 2013).

Broiler piliç rasyonlarında, mısıra ikame olarak \%10, 20 ve 30 oranlarında muz kabuğu ilave edilerek yapılan 4 haftalık bir çalışmada, günlük canlı ağırlık kazancı, günlük yem tüketimi ve kesim ağırlığı bakımından kontrol grubu ile \%10 muz kabuğu içeren grup arasında istatistiki anlamda önemli farklılıklar görülmemiştir. $\% 20$ ve $\% 30$ muz kabuğu içeren gruplarda ise, aynı parametreler için önemli farklılıklar saptanmıştır. Araştırmacı, bitirme rasyonlarına \%10 oranında muz kabuğu ilavesinin broiler piliçlerde herhangi bir olumsuz etkiye neden olmadığ bildirilmiştir (Abel ve ark., 2015).

Fermente edilmiş muz kabuğunun broiler beslenmesinde kullanılabilme imkânlarının araştırıldı ğı bir çalışmada, \%5, 10 ve 15 düzeylerinde muz kabuğu broiler yemlerine ilave edilmiştir. Gruplar arasında günlük yem tüketimi bakımından önemli bir fark oluşmamıştır. Fakat, canlı ağırlık kazancı ve yem dönüşüm oranı bakımından, \%15 oranında muz kabuğu ilaveli yemlerle beslenen grupla diğer gruplar arasında önemli farklılıklar gözlenmiştir. Araştırmacılar, fermente edilmiş muz kabuğunun broiler rasyonlarında $\% 10$ oranında kullanılabileceğini bildirmişlerdir (Koni ve ark., 2013) 
Misıra ikame olarak, enzim ilaveli ve ilavesiz muz kabuğunun broiler rasyonlarında kullanılabilme düzeylerinin araştırıldığ 1 bir çalışmada, \%15, 30 ve 45 oranlarında muz kabuğu içeren rasyonlar hazırlanmış ve 42 gün süreyle besleme yapılmıştır. Çalışmanın sonucuna göre, rasyona muz kabuğu ilavesi broiler piliçlerin performansı üzerine olumsuz bir etkide bulunmamış, enzim ilavesi ise sadece rakamsal olarak bir iyileşme sağlamıştır. Kontrol grubuna nazaran muz kabuğu içeren gruplarda kan kolesterol ve trigriserit düzeyi daha düşük bulunmuştur (Blandon ve ark., 2015).

Sıcaklık stresine maruz bırakılan 21 günlük yaştaki broiler piliçlerin rasyonlarına \%10, 20 ve 30 oranında muz kabuğu ilave edilmiş ve 21 gün boyunca beslenmiştir. Sonuç olarak, kandaki hemoglobin, hematokrit ve alyuvar düzeyi gibi bazı kan parametreleri bakımından gruplar arasındaki farklılıklar önemsiz bulunmuştur. Muz kabuğu içeren rasyonlarla beslenen grupların canlı ağırlık kazancı, kontrol grubuna göre önemli düzeyde düşük bulunmuştur (Hernawan, 2014).

Broiler piliçlerde, misır yerine $\% 5,10$ ve 15 düzeylerinde muz kabuğu ikame edilen rasyonların kullanılmasının etkilerinin araştırıldığı bir çalışmada, kontrol grubu ile muamele grupları arasında günlük yem tüketimi ve ölüm oranı bakımından önemli farklılıklar oluşmamışken, kesim sonu ağırlığı bakımdan önemli farklılıklar görülmüştür. Günlük canlı ağırlık artışı bakımından, kontrol grubu ile $\% 5$ ve $\% 10$ muz kabuğu içeren gruplar arasında önemli bir farklılık oluşmazken, \%15 oranında muz kabuğu içeren grup arasında önemli farklılıklar gözlenmiştir. Yem dönüşüm oranı bakımından, kontrol grubu ile \%10 oranında muz kabuğu içeren grup arasındaki farklılık önemsiz bulunurken, diğer gruplar arasındaki farklılıklar önemli bulunmuştur. Kontrol grubu, kandaki total protein bakımından \%5 muz kabuğu içeren gruptan yüksek ve diğer gruplarla benzer, albümin düzeyi bakımından tüm gruplardan yüksek, glukoz düzeyi bakımından tüm gruplardan düşük, toplam kolesterol bakımından ise muamele grupları ile benzer bulunmuştur. Araştırmacılar, mısıra ikame olarak \%10 oranında muz kabuğu kullanılabileceğini bildirmişlerdir (Duwa ve ark., 2014)

Broiler piliçlerde, sıcaklık stresi üzerine rasyona muz kabuğu ilavesinin etkisinin incelendiği bir çalışmada, hayvanlar $20-34^{\circ} \mathrm{C}$ sicakliklarda kesimden önce 20 gün süreyle muz kabuğu ilaveli rasyonla beslenmişlerdir. Deneme grupları arasında kesim ağırlığı bakımından fark oluşmamış, karkas randımanı bakımından ise kontrol grubu ile $\% 10$ ve $\% 20$ oranında muz kabuğu içeren gruplar benzer bulunmuştur. Muamele gruplarında abdominal yağ oranı kontrol grubuna göre daha düşük bulunmuştur. Araştırmacılar, sıcaklık stresi altında rasyona \%20 oranına kadar muz kabuğu ilavesinin olumlu sonuçlar verdiğini bildirmişlerdir (Widjastuti ve Hernawan, 2012).

Üç haftalık yaştaki ördek palazları ile yapılan besleme çalışmasında rasyona \%20, 30 ve 40 oranında muz kabuğu ilavesi yapılmıştır. Farklı oranlarda muz kabuğu ilavesi, ördeklerin canlı ağırlık artışı ve yem dönüşüm oranı üzerine etkide bulunmazken, yem tüketimini önemli ölçüde etkilemiştir. \%20 ve \%30 oranında muz kabuğu içeren rasyonlarla beslenen gruplar, \%40 muz kabuğu içeren rasyonla beslenen gruba göre daha fazla yem tüketmiştir. Rasyona \%30 oranına kadar muz kabuğu ilavesinin besiye alınan ördekler üzerinde olumsuz bir etki yapmadığı bildirilmiştir (Ulep ve Ayson, 1994).

Rasyona muz kabuğu $(\% 5,10,15)$ ve muz meyvesi ilavesinin $(\% 10,15,20,25,30)$ bıldırcınlar ve etlik piliçler üzerine etkisinin araştırıldığ hafta, etlik piliçler ise 7 hafta boyunca muz kabuğu ve meyvesi ilave edilen rasyonlarla beslenmişlerdir. Muz kabuğu ve meyvesi ilavesi, bıldırcınların canlı ağırlıkları üzerine etkili olmamış, fakat kontrol grubuna oranla yemden yararlanmada önemli bir kötüleşmeye neden olmuştur. Broiler piliçlerde ise, rasyona muz kabuğu ve muz meyvesi ilavesi, büyüme ve yemden yararlanma üzerine olumsuz etkide bulunmuştur (Sirichok, 1992).

Etlik piliç rasyonlarına \%1,5 ve $\% 3$ oranlarında muz kabuğu ve portakal kabuğu ilave edilerek yürütülen 35 günlük bir çalışmada, yem tüketimi hem portakal kabuğu hem de muz kabuğu ilaveli gruplarda kontrol grubuna oranla daha yüksek bulunmuştur. Canlı ağırlık bakımından en yüksek değer \%3 oranında muz kabuğu içeren gruptan elde edilirken, tüm muamele grupları kontrol grubundan daha yüksek canlı ağırlığa sahip olmuşlardır. Yemden yararlanma oranı ve iç organ ağırlıkları bakımından gruplar arasında önemli farklılıklar görülmemiştir. Karkas ağırlığı, muz kabuğu içeren grupta en yüksek bulunurken, tüm muamele grupları kontrol grubuna oranla istatistiki olarak daha yüksek karkas ağırlığına sahip olmuşlardır (Siyal ve ark., 2016).

\section{Nar Kabuğunun Kanatlı Beslenmesinde Kullanımı}

Dünya nar üretiminde önemli bir yere sahip olan ülkemizde 2017 yılı itibarıyla 502 bin ton nar üretimi yapılmıştır (TÜİK, 2017). Nar meyvesinin yaklaşık olarak \%52'sini oluşturan yenilebilir kısmı tüketilmekte veya işlenerek değerlendirilmekte, kalan kısmı ise büyük oranda atılmaktadır (Zarei ve ark., 2011). Nar kabuğunda, \%30,5 kuru madde, \%5,5 kül, \%1,2-2,4 ham yağ, \%3,5-4 ham protein, \%12,6-18,5 lif ve 40,5-190 mg toplam fenolik ve antioksidan bileşikler bulunmaktadır (Kushwaha ve ark., 2013; Saleh ve ark., 2017). Rasyona ilave edilen antioksidanlar yağların oksidatif yıkımını azalttığından dolayı kanatlı rasyonlarında bulunmaları önemlidir (Yassein ve ark., 2015). Ayrıca, okside olmuş yağların kanatlı rasyonlarında oluşturduğu olumsuz etkiler de fenolik bileşiklerle azaltılabilmektedir (Şahin ve Küçük, 2003; Goñi ve ark., 2007). Nar çekirdeği, posası ve kabuğunun içerdiği polifenollerden olan kondense tanenlerin veya proantosiyanidinlerin kolesterolün taşınmasını ve safra asidi atılımını artırarak bağırsaktan kolesterolün emilimini azalttıkları bildirilmiştir (Nakamura ve Tonogai, 2002).

Rasyonlarda çeşitli sentetik koruyucular yıllardır kullanılmaktadır. Meyve ve sebzelerdeki doğal antioksidanlar sentetik olanlara nazaran daha güçlü ektiye ve daha az toksisiteye neden olmaktadır (Marinova ve Yanishlieva, 1997).

Nar kabuğunun antioksidan, antimikrobial, antikanser özelliğe sahip olduğunu, bağışıklık sistemi üzerine olumlu etkide bulunduğu ve çeşitli hastalıkların tedavisinde kullanıldığı çeşitli araştırıcılar tarafından bildirilmiştir (Navarro ve ark., 1996; Gracious ve ark., 2001; Prakash ve Prakash., 2011; Kushwaha ve ark., 2013). 
Fitojenik yem katkı maddelerinin büyüme performansını, besin sindirilebilirliğini ve bağışıklığ iyileştirirken, bağırsak ve dışkıdaki patojen mikroorganizmaları ve dışkıda zararlı gaz oluşumunu azalttı̆̆ bildirilmiştir (Wang ve ark., 2008).

Nar meyvesinin insanlar tarafindan yeterince değerlendirilemeyen \%48'lik gibi büyük bir oranının atılması bazı çevresel problemlere de neden olabilmektedir. $\mathrm{Bu}$ nedenle, hem ekonomik değeri olmayan nar atıklarının ekonomiye kazandırılması ve hem de çevre kirliliğinin azaltılması amacıyla nar kabuğu üzerinde çalışmalar yürütülmüştür.

Broiler rasyonlarında bozulmuş soya yağının nar kabuğu ekstraktı ve adaçayı yağı ilavesi ile kullanılabilirliğinin araştırıldığı 6 haftalık bir çalışmada, $\% 0,05$ ve \%0,1 oranında nar kabuğu ekstraktı içeren gruplar kesim ağırlığı bakımından diğger gruplardan önemli düzeyde yüksek bulunurken, en düşük canlı ağırlık bozulmuş soya yağı içeren grupta ölçülmüştür. Canlı ağırlık kazancı ve yem tüketimi bakımından, nar kabuğu içeren gruplar ve \%0,1 düzeyinde adaçayı yağı içeren grup diğer gruplara oranla daha yüksek değerlere sahip olmuşlardır. (Kishawy ve ark., 2016).

Bıldırcın rasyonlarına nar kabuğu tozu (\%1-1,5) ve sentetik bir antioksidan $(125 \mathrm{~g} / \mathrm{t})$ ilavesinin bazı verim özellikleri ile fizyolojik ve immünolojik parametreler üzerine etkilerinin araştırıldığ 11 haftalık bir çalışmada, canlı ağırlık bakımından en yüksek grup \%1,5 oranında nar kabuğu içeren grup olurken, yem tüketimi ve yem dönüşüm oranı bakımından en yüksek grup kontrol grubu olmuştur. Deneme grupları arasında, yumurta dış kalite özellikleri bakımından elde edilen farklılıklar önemsiz olurken, iç kalite özelliklerinden sarı çapı ve kan kolesterol düzeyi muamele gruplarında kontrol grubuna oranla daha düşük bulunmuştur (Yassein ve ark., 2015).

Bıldırcın rasyonlarında misıra ikame olarak \%2,5\%5 ve 7,5 oranında nar kabuğu tozu ilave edilmiş ve 8 hafta süresince besleme yapılmıştır. Deneme sonunda, gruplar arasında besleme dönem sonu canlı ağırlığı bakımından fark oluşmazken, yem tüketimi bakımından \% 7,5 oranında nar kabuğu içeren grup en yüksek yem tüketimine sahip olmuştur. Yem dönüşüm oranı bakımından kontrol grubuna göre muamele gruplarında azalma görülmüş, yumurta verimi bakımından ise kontrol grubu ile $\% 2,5$ nar kabuğu içeren grup benzer bulunmuştur. Yumurta ağırlığı bakımından, muamele grupları kontrol grubundan daha yüksek değerler vermişlerdir. Kan parametreleri bakımından; toplam protein düzeyi muamele gruplarında kontrol grubundan daha yüksek, muamele gruplarının kolesterol, trigliserit ve glikoz düzeyleri kontrol grubundan daha düşük bulunmuştur (Abbas ve ark., 2017).

Broiler rasyonlarına $\% 0,5$ ve $\% 1$ oranında nar posas 1 ilavesi etkisinin araştırıldığı bir çalışmada, 35 günlük besleme periyodu boyunca gruplar arasında günlük canlı ağırlık artışı bakımından fark oluşmazken, günlük yem tüketimi bakımından kontrol grubu ile $\% 0,5$ oranında nar posası içeren grup arasında fark oluşmamıştır. Yemden yararlanma bakımından muamele grupları kontrol grubuna göre daha iyi bulunmuştur (Ahmed ve Yang, 2017).

Broiler rasyonlarına $\% 0,5, \% 1, \% 1,5$ ve $\% 2$ oranında nar posası ilavesinin etkisinin araştırıldı ğı bir çalışmada, nar posasının gögüs ve but etinin protein, demir, sodyum ve magnezyum düzeylerini önemli düzeyde arttırdığı ve kolesterol düzeyini düşürdüğü bildirilmiştir. Kalsiyum bakımından gruplara arasında fark oluşmamıştır. Göğüs etinin yağ asidi profiline bakıldı ğında, nar posası ilavesinin stearik asit düzeyini azalttığı, eikosapentanoik asit düzeyini ise arttırdığı bildirilmiştir. But etinde ise, palmitik, stearik ve tetrakosaenoik asit düzeylerini azalttığı, heptadekanoik, oleik, $\alpha$-linolenik ve eikosenoik asit düzeylerini arttırdığı bildirilmiştir (Ahmed ve ark., 2015).

\section{Narenciye Kabuklarının Kanatlı Beslenmesinde Kullanımı}

Narenciye üretimi, ülkemizin tarımsal üretiminde çok önemli bir yer tutmakta olup, üretim düzeyi bakımından dünyanın önde gelen ülkelerinden birisi durumundayı. Ülkemizin 2017 yılı narenciye (portakal, mandalina, limon, greyfurt ve turunç) üretimi yaklaşık olarak 4.769.726 ton olarak gerçekleşmiştir (TÜİK, 2017). Narenciye meyveleri, büyük ölçüde yaş olarak tüketimin yanı sıra çeşitli gıda maddelerine işlenerek de tüketilebilmektedir. Yaş olarak tüketilen ve sanayide işlenen narenciyelere ait kabuk ve posalar, hayvan besleme açısından önemli bir potansiyele sahip olan atıklardır. Portakal kabuğu, \%86,2-87,4 kuru madde, \%5,6-7,4 ham protein, \%3-8,19 kül, \%13,5-20 ham lif içermekte olup, $1354-3674 \mathrm{kcal} / \mathrm{kg}$ arasında metabolik enerjiye sahiptir (Aduku, 1993; Hasin ve ark., 2006). Limon kabuğu ise, $\% 9,2$ ham protein, \%17,5 lif, \%6,1 kül, \%0,1 toplam fosfor ve \%1,06 kalsiyum içermektedir (Basir ve Toghyani, 2017). Bu nedenle, farklı yöntemlerle işlenen narenciye kabuk ve posaları kanatlı rasyonlarına çeşitli düzeylerde ilave edilerek etkileri araştırılmıştır. Chaudry ve ark., (2004), broiler rasyonlarına narenciye kabuğu ilavesinin toplam kolesterol ve trigliserit düzeyini düşürdügüunü bildirmiştir. Bazı çalışmalarda, narenciye kabuğunun yumurtacı rasyonlarında performansa olumsuz bir etki yapmadan \%5 düzeyinde kullanılabileceği bildirilmiştir (Karunajeewa, 1978; Velloso, 1985).

Portakal kabuğunun broiler rasyonlarında mısıra ikame olarak kullanılma imkanlarının araştırıldı ̆̆ 8 haftalık bir çalışmada, rasyonlara \%0, 2,5, 5, 7,5 ve 10 oranlarında portakal kabuğu tozu ilave edilerek besi performansı ve kan parametreleri ölçülmüştür. Gruplar arasında günlük yem tüketimi ve ölüm oranı bakımından fark oluşmazken, muamele gruplarının kesim ağırlığı ve günlük canlı ağırlık kazancına ilişkin değerler kontrol grubuna oranla daha düşük bulunmuştur. Günlük yem tüketimi bakımından, $\% 2,5$ ve $\% 5$ oranında portakal kabuğu içeren gruplar kontrol grubu ile benzer sonuçlar verirken, diğer gruplar kontrol grubuna göre daha düşük değerler vermişlerdir. Kandaki hemoglobin, eritrositlerinin hacmi ve toplam eritrosit sayısı bakımından gruplar arasındaki farklılıkların önemsiz olduğu bildirilmiştir (Ojabo ve Adenkola, 2013).

Broiler rasyonlarına portakal kabuğu ilavesinin $(\% 0$, $2,5,5,7,5,10)$ büyüme özellikleri ve kan oksidant düzeyine etkisinin incelendiği 6 haftalık bir çalışmada, kesim ağırlığı ve yem tüketimi bakımından elde edilen değerler muamele gruplarında kontrol grubuna oranla daha düşük bulunmuştur. Yemden yararlanma düzeyi bakımından gruplar arasında önemli farklılıklar oluşmamıştır. Kan antioksidant düzeyi, rasyondaki portakal kabuğu oranına bağlı olarak artış göstermiş olup, en yüksek \%10 oranında portakal kabuğu içeren grupta ölçülmüştür (Faiz ve ark., 2017). 
Narenciye kabuğunun broiler rasyonlarında kullanımının (\%5-10 düzeyinde) araştırıldığı bir çalışmada, yem tüketimi bakımından gruplar arasında önemli bir farklılık görülmemiştir. Günlük canlı ağırlık kazanc1, kesim ağırlığı ve yem dönüşüm oranı bakımından $\% 5$ oranında narenciye kabuğu içeren grup ile kontrol grubu benzer sonuçlar vermiştir. Gruplar arasında iç organ ağırlıkları (kalp, taşlık, karaciğer) bakımından oluşan farklılıklar önemsiz bulunmuştur. Kan kolesterol düzeyi bakımından en düşük değer $\% 10$ oranında narenciye kabuğu içeren grupta görülürken, en yüksek değere kontrol grubu sahip olmuştur (Chaudry ve ark., 2004).

Broiler rasyonlarına $\% 0,5$ ve 10 oranında narenciye kabuğu ve pektinaz ilavesi yapılan 42 günlük bir çalışmada, narenciye kabuğunun rasyondaki oranının artışına bağlı olarak besi performansının olumsuz yönde etkilendiği ve pektinaz enziminin ölçülen parametreleri etkilemediği bildirilmiştir (Dehghani ve ark., 2016)

Broiler rasyonlarına farklı dönemlerde ve farklı düzeylerde katılan kurutulmuş limon kabuğunun performans parametrelerine etkisinin araştırıldığ 1 bir çalışmada, 0-2 haftalık dönemde $\% 2,5,5$ ve 7,5 oranında rasyona katılan limon kabuğu, gruplar arasında canlı ağırlık ve günlük canlı ağırlık kazancı bakımından önemli farklılıklar oluşturmuştur. Günlük yem tüketimi bakımından elde edilen farkl1lıklar ise önemsiz bulunmuştur. Yem dönüşüm oranı bakımından, kontrol grubu ile \%2,5 oranında limon kabuğu içeren gruplar benzer, diğer gruplar ise düşük bulunmuştur. 2-4 haftalık dönemde ise, rasyona $\% 5,7,5$ ve 10 oranında limon kabuğu ilave edilen gruplarda canlı ağırlıklar kontrol grubundan farklı bulunmuştur. Günlük canlı ağırlık artışı ve yem dönüşüm oranı bakımından $\% 5$ oranında limon kabuğu içeren grup ile kontrol grubu benzer, diğer gruplar ise farklı sonuçlar göstermiştir. Günlük yem tüketimi bakımından deneme grupları arasındaki farklılıklar önemsiz olmuştur. 4-6 haftalık dönemde ise, \% 7,5, 10 ve 12 oranında rasyona ilave edilen limon kabuğunun muamele gruplarının canlı ağırlık, günlük canlı ağırlık kazancı ve yem dönüşüm oranlarına etkisi önemli bulunmuştur. Yem tüketimi bakımından, \%10 ve \%12 oranında limon kabuğu içeren gruplarla kontrol grubu arasındaki farklılıklar önemsiz olmuştur. Deneme gruplarına ait karkas verimi, abdominal yağ ve kalp yüzdesi değerleri arasındaki farklılıklar önemsiz olurken, karaciğer yüzdesi bakımından önemli farklılıkların gözlendiği bildirilmiştir (Basir ve Toghyani, 2017).

Kurutulmuş limon kabuğunun broiler rasyonlarında $(\% 0,1,5,3,4,5)$ oranında kullanılma imkanlarının araştırıldığ 42 günlük bir çalışmada, muamele gruplarına ait yem tüketimi ve yem dönüşüm oranı değerleri kontrol grubuna oranla daha yüksek bulunmuştur. Canlı ağırlık kazancı bakımından ise, $\% 3$ ve \%4,5 oranında kurutulmuş limon kabuğu içeren gruplar ile kontrol grubu benzer sonuçlar vermiştir. Karkas randımanı, göğüs, but ve karaciğer yüzdeleri bakımından gruplar arasında önemli bir farklılık oluşmazken, abdominal yağ bakımından \%3 oranında kurutulmuş limon kabuğu grubu hariç diğer gruplar arasındaki farklılıklar önemsiz bulunmuştur. Kandaki kolesterol, trigliserit, ürik asit ve HDL oranları bakımından gruplar arasındaki farklılıklar önemsiz olurken, LDL düzeyi bakımından tüm gruplara ait sonuçların benzer olduğu bildirilmiştir (Nobakht, 2013).
Yumurtacı tavukların rasyonlarına $\% 4$ oranında portakal kabuğu ve kadife çiçeği ilavesinin etkisinin araştırıldığ bir çalışmada, portakal kabuğunun yumurta iç ve dış kalite özellikleri, canlı ağırlık, tavuk/gün yumurta oran1, yumurta ağırlığı ve yem dönüşüm oranı üzerine istatistiksel anlamda önemli bir etki yapmadığ bildirilmiştir (Hasin ve ark., 2006).

Broiler rasyonlarına portakal kabuğu ilavesinin kullanılma düzeylerinin $(\% 0,5,1,1,5,2)$ araştırıldığı bir çalışmada, Portakal kabuğu ilavesi, 0-21 günlük dönemde yem tüketimi, canlı ağırlık artışı ve yemden yararlanma oranını etkilememiştir. 21-35 günlük bitirme periyodunda ise, yemden yararlanmayı olumsuz yönde etkilemiştir. Ayrıca, rasyona portakal kabuğu ilavesinin kan parametreleri üzerine etkisinin önemli olmadığ bildirilmiştir (Abbasi ve ark., 2015).

Broiler rasyonlarına portakal kabuğu ilavesinin $(\% 5$, 10) besi performansı üzerine etkilerinin araştırıldığ 1 bir çalışmada, portakal kabuğu ilavesi canlı ağırlık ve günlük yem tüketimi üzerine olumsuz etkide bulunurken, günlük yem tüketimi ve yem dönüşüm oranı bakımından $\% 5$ oranında portakal kabuğu içeren grup ile kontrol grubu benzer performans göstermiştir. Karkas ağırlığı ve abdominal yağ bakımından $\% 5$ oranında portakal kabuğu içeren gruba ait sonuçlar kontrol grubu ile benzer bulunmuştur. Göğüs etindeki toplam yağ bakımından deneme grupları arasında farklılık görülmezken, \%10 oranında portakal kabuğu içeren grubun kolesterol düzeyi daha düşük bulunmuştur (Mourão ve ark., 2008).

Broiler rasyonlarında misıra (\%30) ikame olarak, $\% 13,3$ düzeyinde fermente edilmemiş, 24 saat fermente edilmiş ve 48 fermente edilmiş portakal kabuğu kurusu içeren 3 farklı rasyonla beslemenin etlik piliçlerin besi performansı üzerine etkileri araştırılmıştır. Çalışmada, canlı ağırlık, günlük canlı ağırlık kazancı ve yem tüketimi bakımından muamele grupları kontrol grubuna oranla daha düşük değerler göstermişlerdir. Yemden yararlanma oranı bakımından ise, tüm gruplar arasındaki farklılıkların önemsiz olduğu bildirilmiştir (Oluremi ve ark., 2010).

Yumurtacı bildircin rasyonlarına $\% 3$ ve $\% 6$ oranında narenciye kabuğu ilavesinin yumurta verimi, yumurta ağırlığı ve kuluçka özellikleri üzerine etkileri araştırılmıştır. \%6 oranında narenciye kabuğu ilavesi, yumurta verimi üzerine önemli bir etki yapmamış, fakat çıkış gücü bakımından kontrol grubuna oranla daha iyi sonuç vermiştir. Ayrıca, narenciye kabuğu içeren grupların kontrol grubuna göre daha ağır yumurta verdikleri bildirilmiştir (Florou-Paneri ve ark., 2001).

Broiler bitirme rasyonlarına farklı düzeylerde $(\% 5,10$, 15) portakal kabuğu ilavesi yapılarak yürütülen bir çalışmada, kesim ağırlığı, günlük canlı ağırlık kazancı, günlük ve toplam yem tüketimine ait değerle, muamele gruplarında kontrol grubuna oranla daha düşük bulunmuştur. \%10 oranına kadar portakal kabuğu içeren gruplar ile kontrol grubuna ait yem dönüşüm oranları benzer bulunmuştur. Günlük protein alımı bakımından ise, $\% 5$ oranında portakal kabuğu içeren grup ile kontrol grubunun benzer sonuçlar gösterdiği bildirilmiştir (Ani ve ark., 2015).

İki haftalık yaştaki bıldırcın rasyonlarına mısıra ikame olarak $\% 0, \% 5, \% 10, \% 15, \% 20$ ve $\% 25$ oranlarında tatl portakal kabuğu ilave edildiğinde, muamele gruplarında canlı ağırlık artışının azaldığı, yemden yararlanma oranlarının ise arttığı bildirilmiştir (Guluwa ve ark., 2014). 


\section{Sonuç}

Broiler rasyonlarına rasyonlarına muz kabuğu ilavesinin genel olarak kan HDL ve trigliserit düzeylerini düşürdüğü, rasyona \%10 oranında ilavesinin genelde verim performansında düşüşe neden olmadığı, daha yüksek oranlarda kullanımının ise canlı ağırlık artışı, yem dönüşüm oranı ve karkas ağırlığını olumsuz yönde etkilediği bildirilmektedir. Ördek rasyonlarına \%30 oranına kadar muz kabuğu ilavesinin besiye alınan ördekler üzerinde olumsuz bir etki yapmadığ bildirilmiştir.

Broiler rasyonlarına \%0,1 oranında nar kabuğu ilavesi, kesim ağırlığı, canlı ağırlık artışını ve yemden yararlanmayı olumlu yönde etkilemektedir. Ayrica, kan kolesterol düzeyini düşürmekte ve toksin içeren yemlerde kullanıldığında toksinlere bağlanarak vücut ağırlığı ile kan değerlerinde iyileşmeye neden olmaktadır. Yapılan çalışmalar, nar kabuğu ilavesinin broiler göğüs eti kalite indekslerini iyileştirdiğini göstermektedir. Bıldırcın rasyonlarına \%1,5 düzeyinde ilave edilen nar kabuğunun canlı ağırlık üzerine olumlu etki yaptığı bildirilmektedir.

Broiler rasyonlarına narenciye kabuğu ilavesinin belirli bir düzeye (\%5) kadar besi performansı üzerine olumsuz bir etki yapmadığı, ancak kullanım düzeyinin artmasına bağlı olarak kesim ağırlığı, canlı ağırlık kazancı ve yemden yararlanmayı düşürdüğü bildirilmektedir. Ayrıca, narenciye kabuğunun kandaki toplam kolesterol ve trigliserit düzeyini düşürdüğü, iç organ ağırlıkları, karkas verimi ve abdominal yă̆ miktarını etkilemediği görülmektedir. Yumurtacı tavukların rasyonlarında narenciye kabuğu kullanımının, yumurtada iç ve dış kalite özelliklerini, canlı ağırlığı, tavuk/gün yumurta oranını, yumurta ağırlığını, yumurta verimini ve yemden yararlanmayı önemli düzeyde etkilemediği görülmektedir. Narenciye kabuğunun yumurtlayan bildırcınların yemlerine katılması durumunda ise yumurta ağırlı̆̆ını olumlu yönde etkilediği bildirilmektedir.

\section{Kaynaklar}

Abbasi H, Seidavi A, Liu W, Asadpour L. 2015. Investigation on the effect of different levels of dried sweet orange (Citrus sinensis) pulp on performance, carcass characteristics and physiological and biochemical parameters in broiler chicken. Saudi J Biol Sci., 22:139-146.

Abel FAS, Adeyemi OA, Oluwole OB, Oladunmoye OO, AyoAjasa OY. 2015. Effects of treated banana peel meal on the feed efficiency, digestibility and cost effectiveness of broiler chickens diet. J Vet Sci Anim Husb 3(1): 101.

Aduku AO. 1993. Feedstuff Analysis Tables. University Press, $\mathrm{ABU}$, Zaria, Nigeria.

Ani AO, Iloh EA, Akinsola OO. 2015. Dietary effect of processed orange peels on growth performance of broiler finisher birds. British Journal of Applied Science and Technology, 9: 576583.

Anhwange BA. 2008. Chemical composition of Musa sapientum (Banana) peels. Journal of Food Technology, 6 (6): 263-266, 2008

Anhwange BA, Ugye TJ, Nyiaatagher TD. 2009. Chemical composition of Musa sapientum (Banana) peels. Electron. J. Environ. Agric. Food Chem. 8, 437-442.

Anwar F, Sriherwanto C, Yunita E, Suja'i I. 2016. Fermentation of Kepok banana peel-corn hominy mixed substrate for dietary inclusion in broiler ration. J Bioteknol Biosains Indones, Vol 3 No 1 Thn Hal 1-6.
Ahmed ST, Islam MM, Bostami ABMR, Mun HS, Kim YJ, Yang CJ. 2015. Meat composition, fatty acid profile and oxidative stability of meat from broilers supplemented with pomegranate (Punica granatum L.) byproducts. Food Chem., 481-488.

Ahmed ST, Yang CJ. 2017. Effect of dietary Punica granatum 1. Byproducts on performance, immunity, intiestinal and fecal microbiology, and odorous gas emissions from excreta in Broilers. Poult Sci., 54: 157-166.

Basir R, Toghyani M. 2017. Effect of dietary graded levels of dried lemon (Citrus aurantifulia) pulp on performance, intestinal morphology, and humoral immunity in broiler chickens. Int J Recycl Org Waste Agricult., 6:125-132.

Blandon JC, Hamady GAA, Abdel-Moneim MA. 2015. The effect of partial replacement of yellow corn by banana peels with and without enzymes on broiler's performance and blood parameters. Journal of Animal and Poultry Sciences, 2015, 4 (1): 10-19.

Chaudry MA, Badshah A, Bibi N, Zeb A, Ahmed T, Ali S, Termeulen U. 2004. Citrus waste utilization in poultry rations. Arch. Geflugelkd. 68 (5), 206-210.

Dehghani ZN, Esmaeilipour O, Mirmahmoudi R, Aminzadeh S. 2017. Effect of pectinase and dried citrus pulp on performance, nutrient digestibility and intestinal characteristics of broiler chickens. Research on Animal Production., Vol. 8, No. 16.

Dividich JL, Geoffrey F, Canope L, Chnost M. 1976. Using waste banana as animal feed. World Animal Review. 67:123-132.

Duwa H, Saleh B, Lamido M, Saidu A. 2014. Growth, haematological and serum biochemical indices of broiler chickens fed banana peel meal as replacement for maize in the semi-arid zone of Nigeria. J Anim Feed Res., 4: 121-6.

Faiz F, Khan MI, Sadiq M, Nawaz H. 2017. Effects of dietary natural antioxidants from citrus waste on growth and blood antioxidants status of the broilers. Sarhad Journal of Agriculture, 33(3): 371-376.

Florou-Paneri P, Babidis V, Kufidis D, Christaki E, Spais AB. 2001. Effect of feding dried citrus pulp on quail laying performance and some egg quality characteristics. Archiv für Geflügelkunde 65(4): 178-181.

Goñi I, Brenes A, Centeno C, Viveros A, Saura-Calixtio F, Rebole A. 2007. Effect of dietary grape pomace and vitamin $\mathrm{E}$ on growth performance. Nutrient Journal of Applied Animal Research. Poult Sci., 86(3):508-516.

Gracious RR, Selvasubramanian S, Jayasundar S. 2001. Immunomodulatory activity of Punica granatum in rabbits $\mathrm{s} A$ preliminary study. J. Ethnopharmacol. 2001, 78: 85-87.

Guluwa L, Madaki YA, Machido H, Dantayi RJ, Kulokom S. 2014. Growth performance and carcass evaluation of quails fed graded levels of water soaked sweet orange peel meal (SOPM). Advances in Life Science and Technology.20: 1-7.

Hang TV, Christopher JS, Quan VV. 2018. Phenolic compounds within banana peel and their potential uses: A review. Journal of Functional Foods 40, 238-248.

Haryanto A, Miharja K, Wijayanti N. 2016. Effects of banana peel meal on the feed conversion ratio and blood lipid profile of broiler chickens. International Journal of Poultry Science, 15: 27-34.

Hernawan E. 2014. Effect of banana peel application in ration on hematological level, nitrogen retention and body weight gain of heat exposed broiler chicken. Scientific Papers. Series D. Animal Science. Vol. LVII.

Hernawati dan AA. 2007. Kajian Sifat Fisik dan Kimia Tepung Kulit Pisang Hasil Pengeringan Oven dan Jemur. FPMIPA Universitas Pendidikan Indonesia. Bandung.

Hasin BM, Ferdaus AJM, Islam MA, Uddin MJ, Islam MS. 2006. Marigold and orange skin as egg yolk color promoting agents. International Journal of Poultry Science. 5 (10): 979-987. 
Kanazawa K, Sakakibara H. 2000. High content of dopamine, a strong antioxidant, in Cavendish banana. J. Agric. and Food Chem., 48, p.844-848.

Karunajeewa H. 1978. Effect of rapeseed and dried citrus pulp meals on egg yolk colour and performance of crossbred hens. J . Austr. Inst. of Agric.Sci., 44 (3-4), 208-209.

Kishawy AT, Omar AE, Gomaa AM. 2016. Growth performance and immunity of broilers fed rancid oil diets that supplemented with pomegranate peel extract and sage oil. Japanese Journal of Veterinary Research., 64(Supplement 2): S31-38.

Koni TNI. 2013. Pengaruh pemanfaatan kulit pisang yang difermentasi terhadap karkas broiler. J Ilmu Ternak dan Vet 18:153-157.

Koni TNI, Bale-Therik J, Kale PR. 2013. Utilizing of fermented banana peels by Rhyzopus oligosporus in ration on growth of broiler. Journal Veteriner September 2013 Vol. 14 No. 3: 365-370.

Koni T, Jublina BT, Pieter RK. 2013. Pemanfaatan kulit pisang hasil fermentasi (Rhyzopus oligosporus) dalam ransum terhadap pertumbuhan ayam pedaging. Jurnal veteriner. 14 (3):365-370.

Kumar KPS, Bhowmik D, Duraivel S, Umadevi M. 2012. Traditional and medicinal uses of banana. Pharmacognosy and Phytochemistry, 1(3), 53-63.

Kushwaha SC., Bera, M.B., Kumar, P., 2013. Nutritional composition of detanninated and fresh pomegranate peel powder. IOSR J. Environ. Sci. Toxicol. Food Technol. 7, 3842.

Marinova EM, Yanishlieva NV. 1997. Antioxidative activity of extracts from selected species of the family Laminacae in sunflower oil. Food Chem., 58: 245.

Mourão JL, Pinheiro VM, Prates JAM, Bessa RJB, Ferreira LMA, Fontes CMG, Ponte PIP. 2008. Effect of dietary dehydrated pasture and citrus pulp on the performance and meat quality of broiler chickens. Poult. Sci., 87:733-743

Nakamura Y, Tonogai Y. 2002. Effect of grape seed polyphenols on serum and hepatic lipid contents and fecal steroid excretion in normal and hypercholesterolemic rats. Journal of Health Science, 48 (6), 570-578.

Navarro V, Villarreal ML, Rojas G, Lozoya X. 1996. Antimicrobial evaluation of some plants used in Mexican traditional medicinefor the treatment of infectious diseases. J. Ethnopharmacol. 53: 143-147.

Nobakht A. 2013. Effects of different levels of dried lemon (Citrus aurantifulia) pulp on performance, carcass traits, blood biochemical and immunity parameters of broilers. Iran J Appl. Anim. Sci., 3:145-151.

Ojabo LD, Adenkola AY. 2013. The growth performance and haematology of cockerel chicks fed with sweet orange (Citrus sinensis) fruit peel meal. Annals of Biological Research, 2013, 4 (10):11-15
Oluremi OIA, Okafor FN, Adenkola AY, Orayaga KT. 2010. Effects of fermentation of sweet orange (Citrus sinensis) fruit peel on its phynutrients and the performance of broiler starter. Int J Poult Sci., 9: 546-549.

Prakash CVS, Prakash I. 2011. Bioactive chemical constituents from pomegranate (Punica ranatum) juice, seed and peel: A review. Int J Res Chem Environ., 1(1):1-18.

Rizal Y, Mahata ME, Andriani M, Wu G. 2010. Utilization juice wastes as corn replacement in the broiler diet. World Academy of Sci. Eng. Technol., 44: 1459-1462.

Saleh H, Golian A, Kermanshahi H, Mirakzehi MT. 2017. Effects of dietary $\alpha$-tocopherol acetate, pomegranate peel, and pomegranate peel extract on phenolic content, fatty acid composition, and meat quality of broiler chickens. Journal of Applied Animal Research, 45:1, 629-636.

Sirichok, T. 1992. Nutritive value of banana meal and banana peeling meal in quail and broiler rations. Master of Thesis, Kasetsart University. 120 p.

Siyal FA, Wagan R, Bhutto ZA, Tareen MH, Arain MA, Saeed M, Brohi SA, Soomro RN. 2016. Effect of orange and banana peels on the growth performance of broilers. Adv. Anim. Vet. Sci., 4(7): 376-380.

Someya S, Yoshiki Y, Okubo K. 2002. Antioxidant compounds from bananas (Musa Cavendish). Food Chem., 79: 351-354.

Şahin K, Küçük O. 2003. Heat stress and dietary vitamin supplementation of poultry diets. Feeds Feed., 73:41R-50R.

TÜIKK. 2017. http://www.tuik.gov.tr. Erişim tarihi: 15.05.2018

Ulep LJL, Ayson AF. 1994. Performance of mallard ducks fed with varying levels of banana (Musa sapientum) peel meal as substitution to corn. DMMMSU Research and Extension Journal.

Velloso L. 1985. Use of citrus pulp in animal feeding. Comunicacoes Cientificas da Faculdade de Medicina Yeterinaria e Zootecnia da Universidade de Sao Paulo 9 (2), 163-180.

Wang Q, Kim HJ, Cho JH, Chen YJ, Yoo JS, Min BJ, Wang Y, Kim IH. 2008. Effects of phytogenic substances on growth performance, digestibility of nutrients, faecal noxious gas content, blood and milk characteristics and reproduction in sows and litter performance. Journal of Animal and Feed Sciences, 17:50-60.

Widjastuti T, Hernawan E. 2012. Utilizing of banana peel (Musa sapientum) in the ration and its influence on final body weight, percentage of carcass and abdominal fat on broilers under heat stress condition. University of Agricultural Sciences and Veterinary Medicine Iasi vol. 57.

Yassein DMM, Abdallah EA, Ismail II, Faddle AA. 2015. Effect of dietary supplementation of pomegranate peel powder and butylated hydroxy toluene on some productive, physiological and immunological parameters of Japanese quail. Egyptian Journal of Animal Production. 52 (Suppl. Issue):105-113.

Zarei M, Azizi M, Bashır-Sadr Z. 2011. Evaluation of physicochemical characteristics of pomegranate (Punica granatum L.) fruit during ripening. Fruits. 66 (2), 121-129. 